\title{
ENERGETIKAI GÉPEK NEM SZABÁLYOS CSAVARFELÜLETEINEK KÖSZÖRÜLÉSE
}

\section{GRINDING OF NON-EXACT HELICAL SURFACES OF ENERGETIC MACHINES}

\author{
Dudás László \\ Miskolci Egyetem, Gépészmérnöki és Informatikai Kar, Alkalmazott Informatikai \\ Tanszék, 3515, Magyarország, Miskolc, Egyetemváros út 1, +36 46 565111/1414, \\ iitdl@uni-miskolc.hu
}

\begin{abstract}
The paper deals with the geometric generation of nonconventional grinding wheel surfaces for grinding the rotor of special type pumps, compressors and expansion machines, engines. For the surface generation the Surface Constructor kinematic simulation and modelling software application was used that is originally intended for the development of new types of gears. The paper reviews the Surface Constructor design system, introduces the special aerohydrodynamic machines and the construction of the applied grinding machine, and reviews the grinding wheel surface modelling.
\end{abstract}

Keywords: aerohydrodynamic machine, grinding, non-exact helical surface, Surface Constructor.

\section{Összefoglalás}

A cikk nem hagyományos köszörükorongok felületének geometriai generálásával foglalkozik, melyekkel speciális szivattyúk, kompresszorok és táguló közeggel működő erőgépek, motorok forgó rotorját lehet megköszörülni. A felületgenerálásra a Surface Constructor kinematikai szimulációs és modellező program került alkalmazásra, mely elsődlegesen fogaskerekek új típusainak kifejlesztésére lett kialakítva. A cikk áttekinti az Surface Constructor tervezőrendszert, bemutatja a speciális aerohidrodinamikus gépeket és az alkalmazott köszörügép konstrukcióját, és ismerteti a köszörükorong felületmodellezését.

Kulcsszavak: aero-hidrodinamikus gép, köszörülés, nem szabályos csavarfelület, Surface Constructor.

\section{Bevezetés}

A legújabb szivattyúfejlesztések eredménye egy új típus, amely csak forgó alkatrészeket tartalmaz, hasonlóan a csavarkompresszorokhoz. A konstrukciót általánosíthatjuk kompresszorokra és táguló közeges erőgépekre, gőzgépekre, motorokra, ha változó emelkedésű csavarfelületet al- kalmazunk. Ezeket az új típusokat, melyek egy forgó kamrát és abban forgó rotort tartalmaznak, az elmúlt években szabadalmaztatták $[9,10]$. Jellemzőjük, hogy a kamra és a rotor között zárt térrészek, üregek alakulnak ki. Amint a forgó alkatrészek mozogni kezdenek, ezek az üregek a forgó alkatrészek tengelyével párhuzamos mozgást végeznek. A résnek a kamra és a rotor között 
a lehető legkisebbnek kell lennie a lehető legjobb tömítés érdekében. Ez különösen fontos a kompresszorok és a táguló közeges erőgépek esetén, ahol a szomszédos kamrák között jelentősebb a nyomáskülönbség. A légzáró tömítés a vékony kenőfilmmel, annak tehetetlenségével biztosítható, hasonlóan a csavarkompresszoroknál alkalmazott módszerhez [11]. A legcélszerübb eljárás ehhez a müködő felületek köszörülése, de ez problémákat is felvet. Az 1. ábrán mutatott szivattyú 1 rotorjának egyenletes emelkedésü csavarfelülete esetén a köszörülés hasonló a csigák köszörüléséhez, és megoldottnak vehető. A forgó kamra belső csavarfelületének köszörülése ennél nehezebb, de szintén lehetséges [3]. A szükséges korongfelület profilja meghatározható pl. a HeliCAD [3], vagy a Surface Constructor (SC) $[4,5]$ programok segítségével. Az ily módon adott forgásfelület alakra a korongok leszabályozhatók CNC korongszabályzókkal.

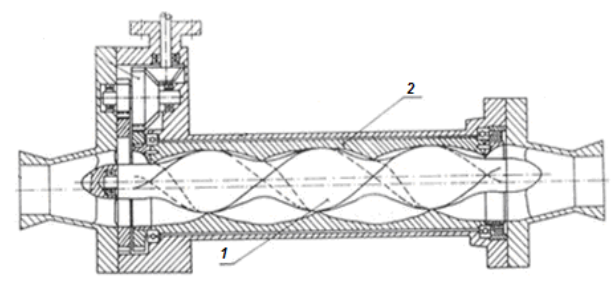

1. ábra. A FORCYL cég által gyártott vízszivattyú

A változó emelkedésű csavarfelületekkel jellemezhető rotorfelületek köszörülése az irodalomban [2] ismertetett speciális köszörügépet és technológiát igényli. A 2. ábrán látható köszörügépek konstrukció kúpos csigák és globoid csigák köszörülése esetén is eredményesen alkalmazható az elméletileg pontos köszörült felület elérésére. Ezen felületek elméleti pontosságú megköszörülése az utóbbi időkig megoldatlan volt, csak speciális esetekre, pl. evolvens kúpos csavarfelületekre, létezett elméleti pontosságú megoldás. A probléma abból ered, hogy a hagyományos, forgásfelület alakú köszörükorong nem képes az alakját köszörülés közben a szükséges mértékben változtatni. A nem egyenletes emelkedésü vagy változó átmérőjü csavarfelületek köszörülése azonban igényli ezt a képességet, mivel a csavarfelület és a korong érintkezési görbéje és ennek következtében az igényelt korongalak pillanatról pillanatra változik. Mivel a hagyományos forgásfelületü köszörükorongok merevek, egy megoldás lehetséges az [1] által ismertetett folyamatos korongszabályozással, amikor is a korong kismértékű alakmódosulását a köszörülés folyamata során az azzal együtt végzett folyamatos CNC korongszabályozással érik el. Ez a technológia kis sorozatok gyártása esetén elönyös, mivel a korongelhasználás jelentős. Egy másik, a szerző találmányában ismertetett megoldás azt a felismerést használja ki, hogy a nem egyenletes csavarfelület eltérő részeivel a korong eltérő felületrészeit kell kapcsoltatni. Egy ilyen korong alakját a csavarfelületről viszszaburkolással lehet előállítani, egy szintén nem egyenletes csavarfelületre emlékeztető felület formájában. A burkolási folyamatnál általában 1:1 áttételt alkalmazunk.

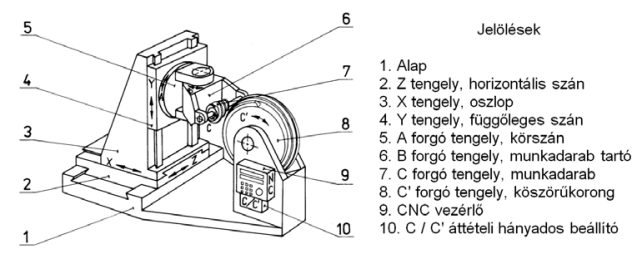

2. ábra. Nem egzakt csavarfelületek elméleti pontosságú köszörülésére alkalmas köszörügép konstrukciója

A módszer alkalmazását spiroid, azaz kúpos alaptestü csiga köszörülése esetére a 3. ábra mutatja, az új köszörügép kinematikai elrendezését használva. Ebben az esetben a számított köszörükorong-felület egy Reishauer típusú csigakorongra emlékeztet, de lényegi különbség, hogy az itt mutatott 
korongfelület önmagában nem elcsavarható müködő felület.

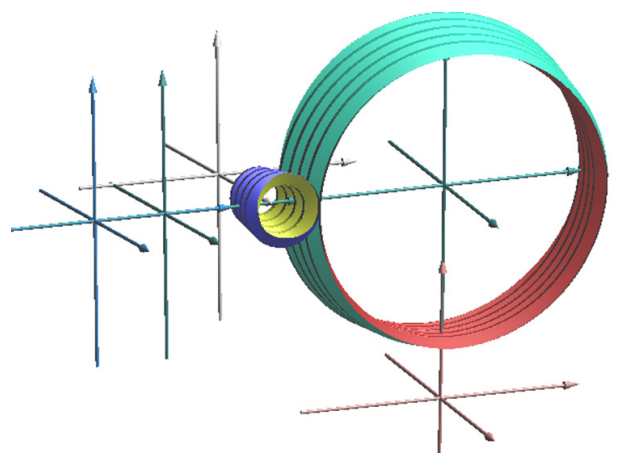

3. ábra. Spiroid csigához generált köszörükorong a speciális köszörügép koordináta-rendszerében

Ezzel az új technológiával, mely a munkadarabot teljes hosszában egyszerre köszörüli, és nem alkalmaz a munkadarab menetárkában történő elötolást, a hagyományos szabályos csavarfelületek, csigák vagy szivattyúrotorok köszörülése szintén lehetséges.

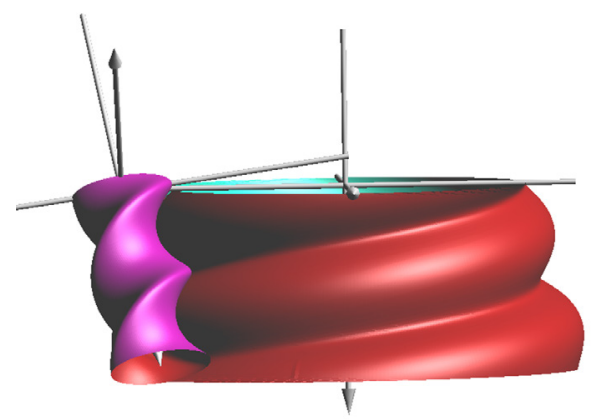

4. ábra. FORCYL-típusú rotor teljes szélességü köszörülésének modellezése

A 4. ábra egy ilyen rotorköszörülésre ad példát. A módszer előnye az elméleti pontosságú köszörülés lehetősége nem szabályos helicoid felületủ munkadarabok esetén is, azonban hátránya a bonyolult és drágán előállítható, bár nagy felületének kö- szönhetően tartós pontosságú köszörükorong elóállitása. Hasonlóan a köszörügép is a drága szerszámgépek csoportjába tartozik. Ezekből eredően a technológia alkalmazása csak nagy sorozatok esetén gazdaságos.

\section{Nem egyenletes emelkedésü csavarfelületek köszörülése}

Az új, innovatív kompresszorok és táguló közeggel müködtetett erőgépek rotorja és forgókamrája nem egyenletes emelkedésü csavarfelületekkel rendelkezik. Az energiaátalakítás irányát a gép forgó részeinek forgásiránya dönti el, megváltoztatva pl. kompresszorból expanziós gép lesz. Mivel ezen gépek konstrukciója meglehetősen új, először ennek bemutatása következik. A rotor és a forgókamra párhuzamos forgási tengelyekkel rendelkezik és azonos irányba forog, de nem azonos fordulatszámmal. Az 5. ábrán láthatjuk a felépítést egy nyitott kamrájú modellen. A kamra és a rotor nagyon kis hézagtól eltekintve vonalak mentén érintkezik, ily módon zárt üregeket közrefogva. Az üregek térfogata a nem egyenletes emelkedésű csavarfelületek alkalmazása miatt változik, és a gép müködése közben a tengelyekkel párhuzamos haladásuk közben nő, illetve csökken, forgásiránytól függően. Növekedés esetén expanziós erögépként, csökkenés esetén kompresszorként alkalmazható. A kompresszió-, illetve expanzióhányados a geometria által meghatározott, nem függ a fordulatszámtól. Az üregek térfogatának tengely menti változását tág határok között változtathatjuk a gép méretezésével. A kamra és a rotor forgásának összehangolását közöttük kialakított kinematikai kapcsolattal, pl. fogaskerekekkel érhetjük el.

A forgókamra köszörülése, illetve finommegmunkálása a rotor köszörülésétől a felület belső elhelyezkedése miatt több problémát vet fel, de pl. a rotorral azonos geometriájú 'köszörükoronggal', vagy 
hónoló szerszámmal elvégezhető. Ekkor kihasználható, hogy a nem egyenletes emelkedés miatt a szerelés is könnyebb a kamra tengelyvonalán átmenő osztósíkkal megosztott két félből való gyártása esetén. Mindenesetre a kamra finommegmunkálása további elemzést kíván, amellyel itt nem foglalkozunk, figyelmünket a rotor köszörülésére irányítjuk. A rotor köszörülése még a javasolt köszörülési technológia és köszörügép alkalmazása mellett is kérdéses, mert fennáll az alámetszés veszélye. Az egyenletes emelkedésü csigák köszörülésével szerzett korábbi tapasztalatokból az tünik célszerünek, hogy a köszörükorongot a legkisebb emelkedésnek megfelelő bedöntési szöggel állítsuk be. A köszörülési folyamat modellezése az SC szoftverrel történt. A korong felületét a rotor felületével burkolva generáltuk, 1:1 fordulatszám-viszony beállítása mellett. Ekkor a korong és a rotor érintkezési pontjaiban a két test érintkező pontjainak kerületi sebessége közel ellentétes irányú, a sebességek abszolút értéke megközelítően összegződik, megfelelő köszörülési sebességet eredményezve, mely a fordulatszámmal állítható. Ebben a származtató mozgásban a származtatófelület és a származtatott felület konjugált felületpárt alkot, a rotor egy pontja a korong egy pontját állítja elő, azzal kapcsolódik. A megmunkálás geometriai korrektségének, alámetszés- és ráhagyásmentességének ellenörzésére két eljárás kínálkozott:

-az érintkezési vonalak megjelenítése és ellenőrzése;

- az $R=R(\Phi)$ függvények megjelenítése és elemzése.

$\mathrm{Az}$ érintkezési vonalak segítségével történő ellenőrzés esetén a felület-felület érintkezést kell látnunk a burkolás minden pillanatában. Az élfelületek kapcsolódás éllel történő felületsúrolást jelentene, nem burkolást, vagy felület általi élburkolás is előfordulhat. Mindkettő az alámetszések speciális esete, és nem kívánatos a köszörü- lési megmunkálás közben. Az érintkezési vonal ellenőrzésének egy pillanatát mutatja az 5. ábra jobb oldala. Az alámetszés lehetősége miatt az érintkezési vonal folytonossága lényeges. Egy szakadás, vagy ugrás az érintkezési görbén azt jelezné, hogy az átugrott szakasznak megfelelő felületrész nem lesz pontosan megköszörülve. Az ábrán látható tökéletes eredmény elérése érdekében a beállításoknál több próba is történt, és elsősorban a korongbedöntési szög finom beállítása volt fontos.

Az érintkezési vonal általi ellenőrzéssel az a gond, hogy egy teljes korongfordulat minden egyes pillanatában el kell végezni. Amint az 5. ábrán is látható, az ellenőrzés megfelelő nézési irány- és nagyításbeállítást kíván minden pillanathoz.
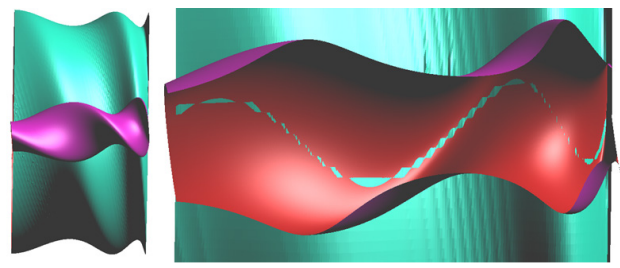

5. ábra. A rotorhoz számitott korong, balra, valamint az érintkezési vonal ellenörzésének egy pillanata Gamma= 5 fokos bedöntési szögnél

Annak ellenére, hogy az SC felhasználói interfésze ebből a szempontból a hasonló 3D szoftverek között is az egyik legkényelmesebben kezelhetö, az ellenőrzési folyamat időigényes és fárasztó. Szerencsére az SC rendelkezik egy egyedi megjelenítési képességgel.

Az $R=R(\Phi)$ függvények megjelenítési lehetősége az SC program kizárólagos képessége. A függvények és a módszer részletes leírása a [6]-ban megtalálható, de az itt bemutatandó ábrák értelmezéséhez egy rövid áttekintést itt is adunk. $\mathrm{Az} R=R(\Phi)$ függvények megjelenítése a rotor és a korong relatív kinematikai viszonyát használja alapinformációként, és a korong felületének 
és a köszörügép beállítási jellemzőinek optimálásához, melyet a relatív sebességek terében végez el. A relatív sebességvektorok helyett a mozgáspálya-vonalakat alkalmazza, mivel azok a sebességvektorok tartóvonalai, és emiatt párhuzamosak azokkal. Ezek a mozgáspályák játsszák a központi szerepet a szerző eredeti Elérés modell nevü kapcsolódásgeometriai elméletében, melyet a [6] elemez részletesen.

\subsection{Az $R=R(\Phi)$ függvények meg- jelenítése}

A legtöbb modern fogaskerékfejlesztő szoftver a Tooth Contact Analysis (TCA) módszert alkalmazza a kapcsolódás jóságának biztosítására. Ez a módszer magába foglalja a felületek közötti hézag függvényének meghatározását a hordkép megjelenítéséhez, és egyaránt alkalmas konjugált és modifikált, hordósított vagy profillenyesést alkalmazó fogaskerekek esetén. Képes az átviteli függvény és a hordkép megjelenítésére, azaz nagyon erőteljes eszköz. Lásd például $[7,8]$. Ez a módszer azonban a kapcsolódó felületek előzetes megadását igényli.

Az SC programban rendelkezésre álló módszer esetén a fejlesztés a mozgáspályák segítségével történik, és a kapcsolódás jellemzőinek javítását és az alámetszések és elmetszések elkerülését a generált felület meghatározása nélkül végezhetjük. A hivatkozott irodalmakból ismert, hogy az $R=R(\Phi)$ függvények kiválóan alkalmasak a lokális alámetszések és a globális elmetszések feltárására. Ezek a jelenségek nagyon veszélyesek nemcsak a fogazatok érintkezésénél, hanem a fogfelületek, burkolt felületek megmunkálásánál is. Elkerülésük az SC rendszerben alkalmazott $R=R(\Phi)$ függvényekkel könnyü. A jó érintkezést egy adott kapcsolódási pontban egy globális maximum pont jellemzi az $\mathrm{R} \rightarrow$ max! extrémumirány választása esetén, és egy globális minimumpont jellemzi az
$\mathrm{R} \rightarrow$ min! extrémumirány választása mellett. A problémás lokális alámetszési helyeket vízszintes érintőjü inflexiós görbealakzat jelzi. A lokális maximummal rendelkező görbék gyakran eredményeznek globális elmetszést, ha a maximumszint $\Phi$ vonala távolabb elmetszi a függvénygörbét. Ez megfigyelhető a 6. ábrán, amikor a $\mathrm{P} 2$ pontot érintő $\Phi$ pályavonal metszi a származtató test metszésvonalát a nagyobb $\Phi$ értéknél. Egyetlen $R=R(\Phi)$ függvénygörbe a származtatott felület egyetlen keletkezö pontját jellemzi. Ha a származtatott felület teljes $T$ - $Z$ tartományát fel szeretnénk tárni a keletkezett pontok kapcsolódásának jósága szempontjából, akkor ehhez az SC-ben erre a célra kialakított vizsgálóablakot használhatjuk, mely a 7. ábrán a jobb oldalon látható. A bal oldal egy lineáris mozgást végző parabolahenger által burkolt sík keletkezését mutatja. Az egyszerü példában a származtató felület metszetgörbéje éppen a származtató felületparabola alkotója. Az ablak lehetöséget ad a függvénygörbék $R=$ $R(\Phi, T)$, vagy $R=R(\Phi, Z)$ seregének felületszerü megjelenítésére is. Amíg a függvényeknél a $\cap$, illetve a $\cup$ alak a kedvező, extrémumirányválasztástól függően, a görbeseregek alkotta vizsgálófelületeknél hegygerinc, illetve völgyalakzat jelzi a hibátlan, alámetszésmentes származtatást. (Az SC az RHO, TAU, ZETA neveket alkalmazza az Elérés modellben alkalmazott $R, T, Z$ helyett.)

A vizsgálóablak a származtatott felület pontjainak keletkezését jellemző $R=R(\Phi)$ függvénygörbék vizsgálatához a következő kényelmes lehetőséget nyújtja: az ablak a $T$ $Z$ tartománynak is megfelel egyben, és bármely pontjára kattintva, az azon $T-Z$ értékekhez tartozó $R=R(\Phi)$ görbe jelenik meg. 


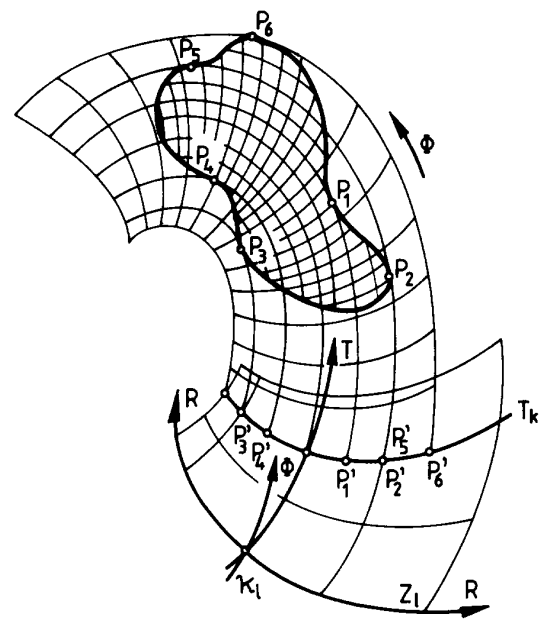

6. ábra. $A z R=R(\Phi)$ függvény kialakulása: a származtató test metszete a $T=$ const; $Z=$ const görbe vonalú koordinátafelületekben

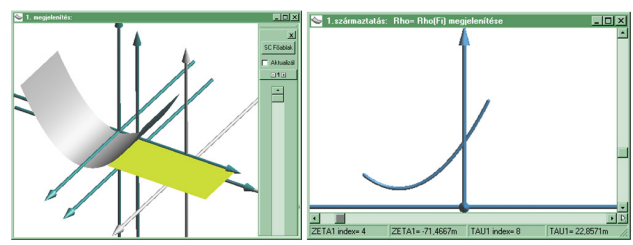

7. ábra. A parabolikus felület általi burkoláskor a keletkezett sík egy pontját a jobb oldali vizsgálóablakban látható parabola alakú metszetgörbe jellemzi a TAUZETA tartomány adott pontjában

A kurzor mozgatásával lenyomott egérgomb mellett a felület tetszőleges tolókákra kattintva egy $R=R(\Phi, T)$ vagy $R=R(\Phi, Z)$ felület jelenik meg, mely alakját változtatja, ha a tolókát mozgatjuk, ily módon a görbeseregek által jellemzett burkolási folyamat minőségének ellenőrzésére könnyü lehetőséget adva, pontjához tartozó függvénygörbe könnyen megjeleníthetö, a $T-Z$ tartomány letapogatható. Az alsó vagy a jobb oldali tolókákra kattintva egy $R=R(\Phi, T)$ vagy $R=R(\Phi, Z)$ felület jelenik meg, mely alakját változtatja, ha a tolókát mozgatjuk, ily módon a görbeseregek által jellemzett burkolási folyamat minőségének ellenőrzésére könnyü lehetőséget ad, amint a 8. ábrán látható. A problémás részeken a hegygerinc-, vagy völgyalakzatok torzulnak, és inflexiós alakzatok, lokális minimumok, illetve maximumok is megjelennek a felületeken, az alámetszések és elmetszések könnyü detektálhatóságát nyújtva.

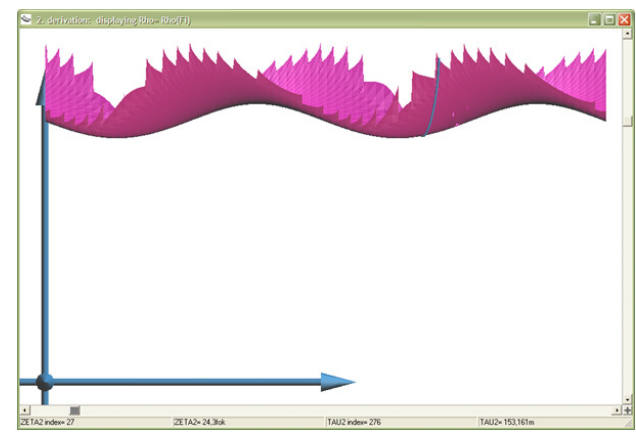

8. ábra. $R=R(\Phi)$ függvények seregeként kialakuló felület

A konkrét köszörükorong-felületre elvégzett ellenőrzés az adott köszörügép beállítási adatok mellett mindenhol kedvező $R=R(\Phi)$ függvényalakokat jelzett, ami a generált köszörükoronggal történő köszörülés geometriai hibátlanságát mutatta.

A számított köszörükoronggal elvégzett megmunkálási szimulációt is mutatja az SC tervezőszoftverről készített pillanatkép a 9. ábrán.

\section{3. Összefoglaló}

A cikkben elemzésre került az újfajta forgó rotorral rendelkező erőgépek rotorjának köszörülése geometriai szempontból. A tapasztalat szerint a változó emelkedésü csavarfelülettel rendelkező rotorok is elvi pontossággal megköszörülhetök egy speciális eljárás és az ahhoz szükséges köszörügép alkalmazásával. A köszörükorong müködő felületének generálásakor alámetszésés elmetszésmentes kialakítást céloztunk 


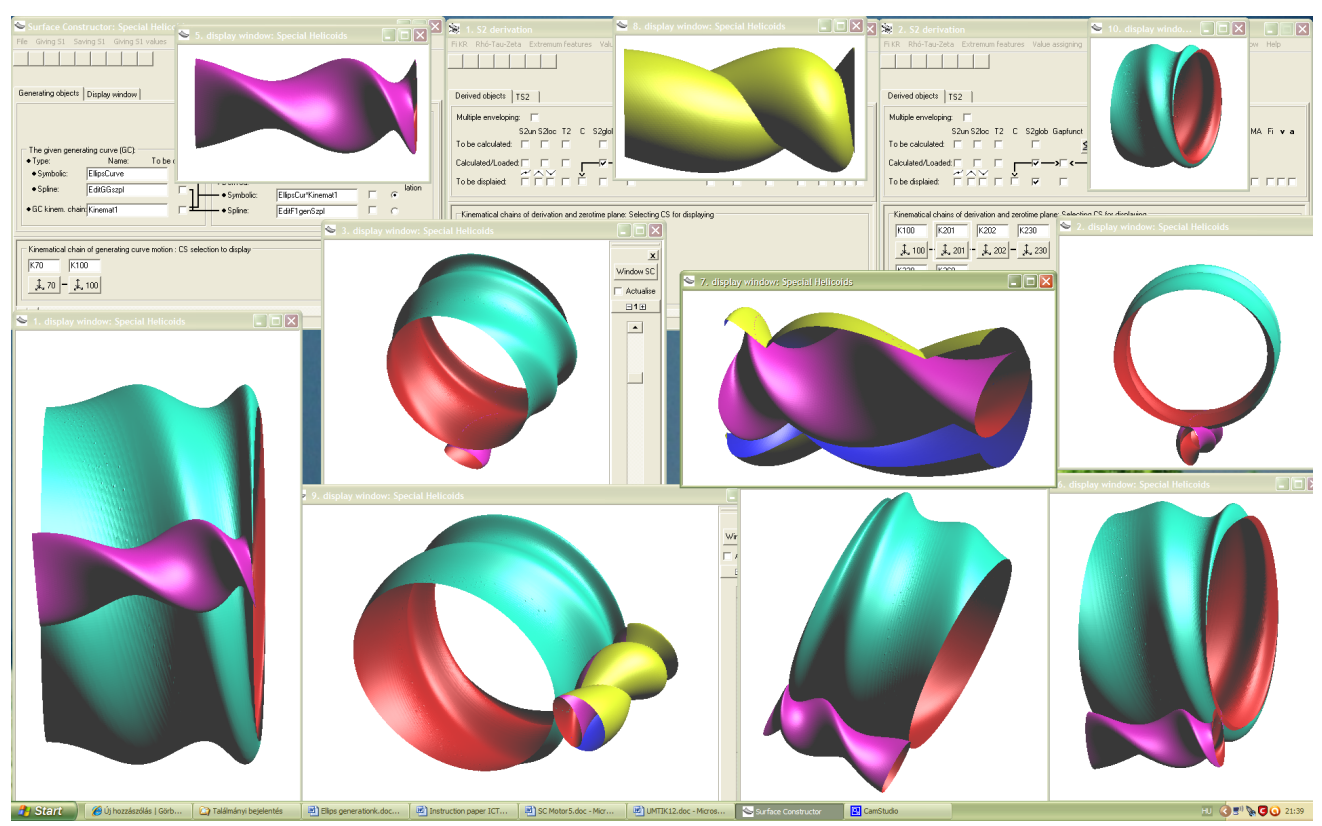

9. ábra. Az SC tervezörendszer a kompresszor és a köszörükorong felületének modellezése közben

meg, melyet sikerült elérni. Az ellenőrzéshez az SC programba beépített $R=R(\Phi)$ függvényvizsgálót alkalmaztuk.

\section{Köszönetnyilvánítás}

A kutatómunka a Miskolci Egyetem stratégiai kutatási területén müködő Mechatronikai és Logisztikai Kiválósági Központ keretében valósult meg.

\section{Szakirodalmi hivatkozások}

[1] Dudás, I.: Grinding possibilities of the conical worm of spiroid driving pairs. Proc. microCAD'96 International Computer Science Conf., Miskolc, Hungary, sect. F, 1996. 33-38.

[2] Dudás, L.: Grinding machine, for grinding non-surface of revolution surfaces, especially conical and globoid worms. Hungarian patent HU P9003803, 1992.

[3] Dudás, L.: Resolution of geometrical problems of contacting surfaces using the Reaching Model. Thesis for Candidate of
Technical Science Degree, Hungarian Academy of Sciences, Budapest, 1993.

[4] Dudás, L.: Advanced software tool for modelling and simulation of new gearings. Int. J. Des. Eng. vol. 3, 2010. 289-310.

[5] Dudás, L.: Gear investigations based on Surface Constructor kinematical modelling and simulation software. Proc. UMTIK 2010 14th Int. Conf. Mach. Des. \& Prod., Güzelyurt, T.R. Northern Cyprus, 731-742.

[6] Dudás, L.: Modelling and simulation of a novel worm gear drive having point-like contact. Proc. TMCE 2010 Symp., Ancona, 685698.

[7] Lunin, S.: Interactive visualization with parallel computing for gear modeling. Letölthető: $\quad$ http://www.zakgear.com/ Parallel.html, Letöltve: 2012.febr.19.

[8] Lunin, S.: New discoveries in WN gear geometry. Letölthető: http://www.zakgear. com/WN.html, Letöltve 2012.febr.19.

[9] Micro Europe Kft: A Sokszögmegmunkálás élvonalában. Letölthető: http://www. microeurope.hu/indexsziv.html, Letöltve 2012.febr.19. 
[10] Murrow, D., Giffin, R. G: Axial flow positive displacement turbine. U.S. Pat. 2009/0226336 A1

[11] Stosic, N., Smith, I. K., Kovacevic, A:
Opportunities for innovation with screw compressors. Proc. IMechE, J. Proc. Mech. Eng., Letölthető: http://www.staff.city.ac.uk / ra601/oportsvi.pdf, Letöltve 2012. febr.19. 